\title{
Pemilihan Alternatif Bahan Baku Fly Ash Menggunakan Metode Fuzzy-Topsis di PT. Semen Gresik
}

\author{
Suseno $^{1}$, Arqi Farady ${ }^{2}$ \\ ${ }^{1,2)}$ Fakultas Sains \& Teknologi, Jurusan Teknik Industri, Universitas Teknologi Yogyakarta \\ Jl. Glagahsari no 63 Umbulharjo Yogyakarta \\ Email: suseno@uty.ac.id, arqi.farady@gmail.com
}

\begin{abstract}
ABSTRAK
PT Semen Gresik Rembang merupakan salah satu perusahaan semen yang ingin memanfaatkan kembali limbah B3 (Bahan Berbahaya dan Beracun). Perusahaan berencana untuk memilih alternatif diantara fly ash kelas $\mathrm{F}$ dan $\mathrm{C}$ dengan pertimbangan kriteria pozzolan, $\mathrm{SO}_{3}, \mathrm{Na}_{2} \mathrm{O}$, dan kuat tekan. Kandungan fly ash kelas $\mathrm{F}$ pozzolan $83,95 \%, \mathrm{SO}_{3} \mathrm{0}, 49 \%, \mathrm{Na}_{2} \mathrm{O} 2,21 \%$, kuat tekan 95,53 Mpa dan kandungan fly ash kelas C pozzolan 74\%, $\mathrm{SO}_{3}$ $2,97 \%, \mathrm{Na}_{2} \mathrm{O} 2,20 \%$, dan kuat tekan 65,04 Mpa. Penelitian ini bertujuan untuk menentukan alternatif bahan baku fly ash terbaik berdasarkan kriteria yang ditentukan. Penelitian ini menggunakan metode Fuzzy-TOPSIS. Penelitian ini pertama melakukan penentuan membentuk fungsi keanggotaan, menetukan nilai keanggotaan, inferensi sistem terhadap aturan fuzzy, melakukan normalisasi bobot matriks, menentukan solusi ideal positif, menentukan solusi ideal negatif, menentukan separation measure, menentukan kedekatan relatif, dan melakukan perangkingan alternatif yang dapat digunakan sebagai pemilihan alternatif terbaik. Pemilihan alternatif terbaik dilihat berdasarkan kandungan yang dimiliki pada masing-masing kriteria. Kandungan pada masing-masing kriteria dilakukan pengolahan data untuk menentukan hasil terbaik yang akan diterapkan di perusahaan. Diperoleh hasil penelitian fly ash kelas F V1 $=0,24947$ dan kelas C V2 $=0,75053$. Berdasarkan perangkingan alternatif, fly ash kelas $\mathrm{C}$ dipilih sebagai bahan baku penunjang produksi semen.
\end{abstract}

Kata kunci : fly ash, kuat tekan, fuzzy-TOPSIS, perangkingan

\begin{abstract}
PT Semen Gresik Rembang is one of the cement companies which want to reuse B3 waste (Toxic and Hazardous Waste). The Company plans to choose between fly ash class $\mathrm{F}$ and $\mathrm{C}$ by considering pozzolan, $\mathrm{SO}_{3}$, $\mathrm{Na}_{2} \mathrm{O}$, and compressive strength. The contents of fly ash class $\mathrm{F}$ are $83.95 \%$ pozzolan, $0.49 \% \mathrm{SO}_{3}, 2.21 \% \mathrm{Na}_{2} \mathrm{O}$, and $95.53 \mathrm{Mpa}$ of compressive strength and the contents of fly ash class C are $74 \%$ pozzolan, $2.97 \% \mathrm{SO}_{3}, 2.20 \%$ $\mathrm{Na}_{2} \mathrm{O}$, and 65.04 Mpa of compressive strength. The present study aimed to determine the best fly ash alternative based on the set criteria. The present study used fuzzy-TOPSIS method. This research first determines the formation of membership functions, determines membership values, system inference to fuzzy rules, normalizes matrix weights, determines positive ideal solutions, determines negative ideal solutions, determines the separation measure, determines relative closeness, and performs alternative ranking that can be used as selection of the best alternatives. The content in each criteria was processed to determine the best result to be set in the company. The results of the research obtained from class $F$ fly ash $V 1=0,24947$ and class $C V 2=$ 0,75053.Based on ranking, fly ash class $C$ was selected to be the supporting material for cement production.
\end{abstract}

Keywords: fla Ash, compressive strength, fuzzy-TOPSIS, rank

\section{PENDAHULUAN}

PT Semen Gresik Rembang merupakan salah satu perusahaan semen yang ingin memanfaatkan kembali limbah B3 (Bahan Beracun dan Berbahaya). Fly ash (abu terbang) merupakan sisa dari pembakaran batu bara pada PLTU (Pembangkit Listrik Tenaga Uap). Fly ash dapat dimanfaatkan sebagai bahan baku penunjang semen dikarenakan memiliki kandungan yang bersifat pozzolan. Sifat pozzolan yaitu bahan yang mengandung silika atau alumina silika yang tidak mempunyai sifat perekat (sementasi) pada dirinya sendiri tetapi dengan butiran halus yang dimiliki dapat bereaksi secara kimia dengan kapur dan air membentuk bahan perekat pada temperatur normal sehingga dapat digunakan sebagai bahan baku penunjang produksi semen. 
Terdapat dua jenis klasifikasi fly ash di dalam perusahaan yaitu fly ash kelas F dan C. Penggunaan fly ash sebagai bahan baku penunjang produksi semen yaitu dapat menghemat kapasitas penggunaan bahan baku utama produksi semen. Dalam suatu perusahaan tentu ingin menghemat penggunaan bahan baku utama untuk menghasilkan produk semen dengan kualitas yang sama. Maka dari itu perusahaan kesulitan dalam memilih fly ash mana yang terbaik sebagai bahan baku penunjang produksi semen.

Masing-masing klasifikasi fly ash memiliki batasan maksimum dan minimum persentase kandungan kimiawi. Kriteria fly ash terbaik memiliki kandungan pozzolan minimum 70\%, $\mathrm{SO}_{3}$ maksimum 50\%, dan $\mathrm{Na}_{2} \mathrm{O}$ maksimum 1,5\% dan kuat tekan minimum 75 Mpa (Sutter et al., 2013). Berdasarkan data dari perusahaan terdapat kandungan dari masing-masing kelas fly ash. Pada fly ash $\mathrm{F}$ terdapat kandungan pozzolan $\mathrm{SiO}_{2}+$ $\mathrm{Al}_{2} \mathrm{O}_{3}+\mathrm{Fe}_{2} \mathrm{O}_{3}$ sebesar 83,9553, kandungan $\mathrm{SO}_{3}$ sebesar 0,49324667, kandungan $\mathrm{Na}_{2} \mathrm{O}$ sebesar 2,21007333, dan kandungan kuat tekan fly ash pada kapasitas campuran 20\% sebesar 95,53 Mpa. Pada fly ash $\mathrm{C}$ terdapat kandungan pozzolan $\mathrm{SiO}_{2}+\mathrm{Al}_{2} \mathrm{O}_{3}+\mathrm{Fe}_{2} \mathrm{O}_{3}$ sebesar 74,0036, kandungan $\mathrm{SO}_{3}$ sebesar 2,9785, kandungan $\mathrm{Na}_{2} \mathrm{O}$ sebesar 2,202, dan kandungan kuat tekan fly ash pada kapasitas campuran 20\% sebesar 65,04 Mpa.

Dari data penelitian perusahaan terhadap fly ash yang akan digunakan dapat diketahui bahwa setiap kelas fly ash memiliki persentase kandungan kimia yang berbeda-beda. Fly ash juga mempunyai beberapa kriteria sebagai syarat untuk digunakan dalam proses produksi. Kandungan kimia terdapat dari masing-masing kriteria di dalam fly ash. Kriteria fly ash $\mathrm{F}$ dan $\mathrm{C}$ meliputi pozzolan $\mathrm{SiO}_{2}+\mathrm{Al}_{2} \mathrm{O}_{3}+\mathrm{Fe}_{2} \mathrm{O}_{3}, \mathrm{SO}_{3}, \mathrm{Na}_{2} \mathrm{O}$, dan kuat tekan. Dilihat dari perbedaan kandungan masing-masing kriteria, maka akan dipilih fly ash kelas mana yang memiliki hasil uji yang paling mendekati kriteria terbaik.

Selain memanfaatkan limbah sebagai bahan baku penunjang produksi semen, fly ash juga merupakan buangan yang mengandung zat yang beracun dan berbahaya. Sehingga secara langsung maupun tidak langsung dapat merusak lingkungan, mengganggu kesehatan, dan mengancam kelangsungan hidup manusia serta organisme lainya.

Metode Fuzzy-TOPSIS dapat digunakan sebagai pilihan untuk menyelesaikan permasalahan ketidakpastian penentu keputusan (Syahputra, 2014). Sedangkan menurut Sari, (2015) bahwa Metode TOPSIS merupakan metode sistem pendukung keputusan yang bisa memecahkan berbagai masalah pengambilan keputusan multikriteria. Beberapa peneliti juga menggunakan fuzzy TOPSIS untuk diaplikasikan dalam kasus yang berbeda. Chu \& Lin, (2003) menerapkan Fuzzy TOPSIS untuk pemilihan robot. 'Uyun \& Riadi (2011) menggunakan Fuzzy TOPSIS untuk seleksi mahasiswa penerima beasiswa. Adapun Azizi et al., (2015) menggunakan Fuzzy TOPSIS untuk pemilihan supplier otomotif. Kabir \& Hasin (2012) menggunakan TOPSIS dan Fuzzy TOPSIS untuk memilih kuaitas layanan travel di Bangladesh, dan kemudian membandingkan hasilnya

\section{Landasan Teori Fly Ash}

Fly ash merupakan sisa dari pembakaran batu bara pada PLTU (Pembangkit Listrik Tenaga Uap). Fly ash biasanya mengacu pada abu yang dihasilkan selama pembakaran batu bara. Fly ash umumnya ditangkap oleh pengendap elektrostatik atau peralatan filtrasi partikel lain sebelum gas buang mencapai cerobong asap batu bara pembangkit listrik, dan bersama-sama dengan bottom ash dikeluarkan dari bagian bawah tungku dalam hal ini bersama-sama dikenal sebagai abu batu bara. Tergantung pada sumber dan tampilan batu bara yang dibakar, komponen fly ash bervariasi, tetapi semua fly ash termasuk sejumlah besar silikon dioksida $\left(\mathrm{SiO}_{2}\right)$, baik amorf kristal, dan kalsium oksida $(\mathrm{CaO})$. Kedua bahan endemik yang banyak terdapat di dalam lapisan batuan batu bara yang dapat dimanfaatkan sebagai salah satu bahan baku produksi semen yang memiliki sifat pozzolan.

Pozzolan adalah bahan yang mengandung senyawa silika atau silika alumina dan alumina, yang tidak mempunyai sifat mengikat seperti semen akan tetapi dalam bentuk yang halus dan dengan adanya air maka senyawa-senyawa tersebut akan bereaksi dengan kalsium hidroksida pada suhu normal membentuk senyawa kalsium hidrat yang bersifat hidraulis dan mempunyai angka kelarutan yang cukup rendah atau bersifat reaktif. Pozzolan mempunyai mutu yang baik apabila jumlah kadar $\mathrm{SiO}_{2}+\mathrm{Al}_{2} \mathrm{O}_{3}+\mathrm{Fe}_{2} \mathrm{O}_{3}$ tinggi dan reaktifitasnya tinggi dengan kapur. Ketiga kelas pozzolan tersebut adalah:

1. Kelas N: Pozzolan alam atau hasil pembakaran, pozzolan alam yang dapat digolongkan didalam jenis ini seperti tanah diatomoic, opaline cherts, shales, tuff, dan pumicite (abu vulkanik), dimana bisa diproses melalui pembakaran atau tidak. Selain itu juga berbagai material hasil pembakaran yang mempunyai sifat pozzolan yang baik.

2. Kelas C: Fly ash yang mengandung $\mathrm{CaO}$ di atas $10 \%$ yang dihasilkan dari pembakaran lignite atau subbitumen batubara. 
3. Kelas F: Fly ash yang mengandung $\mathrm{CaO}$ kurang dari $10 \%$ yang dihasilkan dari pembakaran lignite atau subbitumen batu bara.

Berikut merupakan persyaratan kimia menggunakan panduan ASTM (American Standard Testing and Material):

Tabel 1. Persyaratan Kimia

\begin{tabular}{|c|c|c|c|}
\hline \multirow{2}{*}{ Komposisi } & \multicolumn{3}{|c|}{ Kelas } \\
\hline & $\mathrm{N}$ & $\mathrm{F}$ & $\mathrm{C}$ \\
\hline Pozzolan $\mathrm{SiO}_{2}+\mathrm{Al}_{2} \mathrm{O}_{3}+\mathrm{Fe}_{2} \mathrm{O}_{3}(\mathrm{~min}, \%)$ & 70,0 & 70,0 & 50,0 \\
\hline $\mathrm{SO}_{3}(\max , \%)$ & 4,0 & 5,0 & 5,0 \\
\hline $\mathrm{Na}_{2} \mathrm{O}(\max , \%)$ & 1,5 & 1,5 & 1,5 \\
\hline Kuat Tekan (min) & $75 \mathrm{Mpa}$ & $75 \mathrm{Mpa}$ & $75 \mathrm{Mpa}$ \\
\hline
\end{tabular}

\section{Logika Fuzzy}

Bahroini et al., (2016) menjelaskan bahwa logika fuzzy memiliki derajat keanggotaan dalam rentang 0 hingga 1. Berbeda dengan logika digital yang hanya memiliki dua nilai 1 atau 0. Logika fuzzy digunakan untuk menerjemahkan suatu besaran yang diekspresikan menggunakan bahasa (linguistic), misalkan besaran kecepatan laju kendaraan yang diekspresikan dengan pelan, agak cepat, cepat, dan sangat cepat. Dan logika fuzzy menunjukan sejauh mana suatu nilai itu benar dan sejauh mana suatu nilai itu salah. Logika fuzzy adalah suatu cara yang tepat untuk memetakan suatu ruang input kedalam suatu ruang output. Fuzzy dinyatakan dalam derajat dari suatu keanggotaan dan derajat dari kebenaran. Oleh sebab itu sesuatu dapat dikatakan sebagian benar dan sebagian salah pada waktu yang sama.

Tahapan-tahapan dalam metode Fuzzy yang digunakan yaitu sebagai berikut (Kusumadewi \& Purnomo, 2010)

Pada tahapan ini variabel input dari sistem fuzzy dibuat ke dalam himpunan fuzzy untuk dapat digunakan dalam perhitungan. Pada tahap ini menentukan derajat keanggotaan dari setiap himpunan fuzzy. Himpunan fuzzy yang digunakan dalam penelitian ini menggunakan 3 fungsi keanggotaan, yaitu:

a. Fungsi linear turun

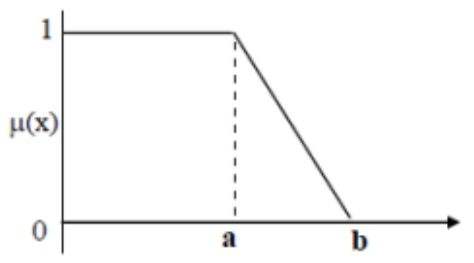

Domain (x)

Gambar 1. Fungsi Linear Turun

$$
\mu(x)=\left\{\begin{array}{cc}
1 ; & x \leq a \\
(b-x) /(b-a) & a \leq x \geq b \\
0 ; & x \geq b
\end{array}\right.
$$

b. Fungsi linear naik

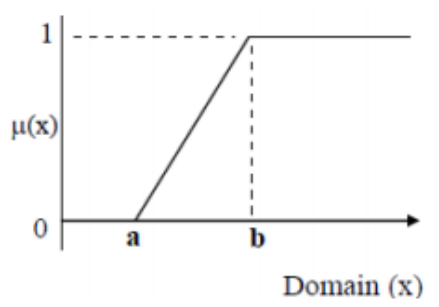

Gambar 2. Fungsi Linear Naik

$$
\mu(x)=\left\{\begin{array}{cc}
0 ; & x \leq a \\
(x-a) /(b-a) & a \leq x \geq b \\
1 ; & x \geq b
\end{array}\right.
$$




\section{TOPSIS}

Sari (2015) menjelaskan bahwa TOPSIS (Technique for Others Reference by Similarity to Ideal Solution) adalah salah satu metode pengambilan keputusan multi-kriteria yang pertama kali diperkenalkan oleh Yoon dan Hwang pada tahun 1981. TOPSIS menggunakan prinsip bahwa alternatif yang terpilih harus mempunyai jarak terdekat dari solusi ideal positif dan terjauh dari solusi ideal negatif dari sudut pandang geometris dengan menggunakan jarak euclidean untuk menentukan kedekatan relatif dari suatu alternatif dengan solusi optimal. Solusi ideal positif didefinisikan sebagai jumlah dari seluruh nilai terbaik yang dapat dicapai untuk setiap atribut, sedangkan solusi negatif-ideal terdiri dari seluruh nilai terburuk yang dicapai untuk setiap atribut. TOPSIS mempertimbangkan keduanya, jarak terhadap solusi ideal positif dan jarak terhadap solusi ideal negatif dengan mengambil kedekatan relatif terhadap solusi ideal positif. Berdasarkan perbandingan terhadap jarak relatifnya, susunan prioritas alternatif bisa dicapai. Metode ini banyak digunakan untuk menyelesaikan pengambilan keputusan. Hal ini disebabkan konsepnya sederhana, mudah dipahami, komputasinya efisien, dan memiliki kemampuan mengukur kinerja relatif dari alternatif-alternatif keputusan.

Berikut merupakan angkah-langkah dari metode topsis: (Papilo et al., 2018)

1. Normalized Decision Matrix

Membangun normalized decision matrix elemen rij hasil dari normalisasi decision matrix $R$ dengan metode euclidean length of a vector adalah:

Dimana:

$$
r_{i j}=\frac{x_{i j}}{\sqrt{\sum_{i}^{m}=1 x^{2}}}
$$

$R_{i j}=$ hasil dari normalisasi matriks keputusan $R$

$i=1,2,3, \ldots, m$;

$j=1,2,3, \ldots, n$;

2. Weighted Normalized Decision Matrix

Membangun weighted normalized decision matrix dengan bobot $W=(w 1, w 2, \ldots, w n)$, maka normalisasi bobot matriks $V$ adalah:

$$
Y=\left[\begin{array}{ccc}
w_{11} r_{11} & \cdots & w_{1 n} r_{1 n} \\
\vdots & \ddots & \vdots \\
w_{m 1} r_{m 1} & \cdots & w_{n m} r_{n m}
\end{array}\right]
$$

3. Solusi Ideal Positif dan Solusi Ideal Negatif

Menentukan solusi ideal positif dan solusi ideal negatif. Solusi ideal positif dinotasikan dengan $A^{+}$dan solusi ideal negatif dinotasikan dengan $A^{-}$, sebagai berikut:

Menentukan solusi ideal (+) dan (-)

$$
\begin{aligned}
& A^{+}=\{(\max a i j)(\min a i j \mid j \epsilon J), i=1,2,3, \ldots . m\}=\left\{V 1^{+} V 2^{+}, \ldots V m^{+}\right\} \\
& A^{-}=\{(\max a i j)(\min a i j \mid j \epsilon J), i=1,2,3, \ldots . m\}=\left\{V 1^{-} V 2^{-}, \ldots V m^{-}\right\} \\
& \text {Dimana: } \\
& V i j=\text { elemen matriks } V \text { baris ke- } i \text { dan kolom ke- } j \\
& J=\{j=1,2,3, \ldots . n \text { dan } j \text { berhubungan dengan benefit }\} \\
& J=\{j=1,2,3, \ldots . n \text { dan } j \text { berhubungan dengan cost criteria }\}
\end{aligned}
$$

\section{Separation Measure}

Menghitung separation measure ini merupakan pengukuran jarak dari suatu alternatif ke solusi ideal positif dan solusi ideal negatif. Perhitungan matematisnya adalah sebagai berikut:

a. Separation measure untuk solusi ideal positif.

$$
D i^{+}=\sqrt{\sum_{j=1}^{a}\left(v_{i j}-v_{j}^{+}\right)^{2}} \text { dengan } i=1,2,3, \ldots m
$$

Dimana:

$J=\{j=1,2,3 \ldots, n$ dan $j$ merupakan benefit criteria $\}$

$J^{\prime}=\{j=1,2,3 \ldots ., n$ dan $j$ merupakan costcriteria $\}$

b. Separation measure untuk solusi ideal negatif

$$
D i^{-}=\sqrt{\sum_{j=1}^{a}\left(v_{i j}-v_{j}^{-}\right)^{2}} \text { dengan } i=1,2,3, \ldots n
$$

5. Kedekatan Relatif Solusi Ideal

Menghitung kedekatan relatif terhadap solusi ideal. Kedekatan relatif dari alternatif $A+$ dengan solusi ideal $A$ - direpresentasikan dengan: 


$$
V_{i}=\frac{D_{i}^{-}}{D_{i}^{-}+D_{i}^{+}} \text {dengan } 0<V_{i}^{+} \text {dan } i=1,2,3, \ldots, m
$$

6. Perangkingan Alternatif

Merangking alternatif, alternatif dapat diranking berdasarkan urutan $V i^{*}$. Maka dari itu, alternatif terbaik adalah salah satu yang berjarak terpendek terhadap solusi ideal positif dan berjarak terjauh dengan solusi ideal negatif.

\section{METODE PENELITIAN}

Jenis penelitian yang digunakan adalah penelitian dengan pendekatan kuantitatif. Penelitian difokuskan pada pemilihan alternatif bahan baku fly ash. Data yang diperoleh terdiri dari pemilihan alternatif bahan baku, data kriteria bahan baku, dan identifikasi prioritas kriteria yang terdapat dalam perusahaan. Fokus penelitian yang lain yaitu adalah alternatif pemilihan bahan baku dengan menggunakan metode fuzzy-TOPSIS yang terdiri dari membentuk fungsi keanggotaan, menetukan nilai keanggotaan, inferensi sistem terhadap aturan fuzzy, melakukan normalisasi bobot matriks, menentukan solusi ideal positif, menentukan solusi ideal negatif, menentukan separation measure, menentukan kedekatan relatif, dan melakukan perangkingan alternatif.

Berikut merupakan uraian metode penelitian:

1. Pengumpulan Data

Pengumpulan data dilakukan setelah mengetahui masalah yang ada di dalam perusahaan, yaitu pemilihan kelas fly ash mana yang lebih penting untuk digunakan sebagai bahan baku penunjang produksi semen. Data yang digunakan dari masing-masing kriteria fly ash kelas F dan C. Pada fly ash F terdapat kandungan pozzolan sebesar 83,9553, kandungan $\mathrm{SO}_{3}$ sebesar 0,49324667, kandungan $\mathrm{Na}_{2} \mathrm{O}$ sebesar 2,21007333, dan kandungan kuat tekan fly ash pada kapasitas campuran 20\% sebesar 95,53 Mpa. Pada fly ash $\mathrm{C}$ terdapat kandungan pozzolan $\mathrm{SiO}_{2}+\mathrm{Al}_{2} \mathrm{O}_{3}+\mathrm{Fe}_{2} \mathrm{O}_{3}$ sebesar 74,0036, kandungan $\mathrm{SO}_{3}$ sebesar 2,9785, kandungan $\mathrm{Na}_{2} \mathrm{O}$ sebesar 2,202, dan kandungan kuat tekan fly ash pada kapasitas campuran 20\% sebesar 65,04 Mpa.

2. Pengolahan Data

Pengolahan data dilakukan menggunakan metode Fuzzy-TOPSIS, dengan langkah-langkah sebagai berikut:

a. Membentuk Fungsi Keanggotaan

b. Menentukan Nilai Keanggotaan

c. Normalisasi Bobot Matriks

d. Solusi Ideal Positif

e. Solusi Ideal Negatif

f. Separation Measure

g. Kedekatan Relatif

h. Perangkingan Alternatif

Dalam pembahasan berisi tentang seluruh hasil dari pengolahan data dan akan dibentuk dalam suatu ringkasan berdasarkan perangkingan penggunaan fly ash yang lebih penting sebagai bahan baku penunjang untuk proses produksi semen.

\section{HASIL DAN PEMBAHASAN}

Fly ash dibagi menjadi 3 kelas yaitu kelas N, F, dan C. PT Semen Gresik hanya merencanakan penggunaan fly ash kelas $\mathrm{F}$ dan $\mathrm{C}$ dikarenakan kelas $\mathrm{N}$ diperoleh dari sisa abu vulkanik gunung berapi, sehingga perlu upaya yang lebih besar untuk memperolehnya. Berikut merupakan persyaratan kimia berdasarkan karakteristik fly ash kelas F dan C ( Sutter, et al., 2013)

Tabel 2. Persyaratan Kimia

\begin{tabular}{|c|c|c|}
\hline \multirow{2}{*}{ Komposisi } & \multicolumn{2}{|c|}{ Kelas } \\
\hline & $\mathrm{F}$ & $\mathrm{C}$ \\
\hline Pozzolan $\mathrm{SiO}_{2}+\mathrm{Al}_{2} \mathrm{O}_{3}+\mathrm{Fe}_{2} \mathrm{O}_{3}(\mathrm{~min}, \%)$ & 70,0 & 50,0 \\
\hline $\mathrm{SO}_{3}(\max , \%)$ & 5,0 & 5,0 \\
\hline $\mathrm{Na}_{2} \mathrm{O}(\max , \%)$ & 1,5 & 1,5 \\
\hline Kuat Tekan & $75 \mathrm{Mpa}$ & $75 \mathrm{Mpa}$ \\
\hline
\end{tabular}

Di atas merupakan tabel persyaratan kimia untuk penentuan kelas fly ash yang sesuai dengan standar ASTM (America Standard Testing and Material). Fly ash bisa dikatakan kelas F jika kriteria pozzolan $\left(\mathrm{SiO}_{2}+\right.$ $\mathrm{Al}_{2} \mathrm{O}_{3}+\mathrm{Fe}_{2} \mathrm{O}_{3}$ ) dengan data kandungan $\geq 70 \%, \mathrm{SO}_{3} \leq 5 \%, \mathrm{Na}_{2} \mathrm{O} \leq 1,5$, dan kuat tekan $75 \mathrm{Mpa}$. Fly ash bisa 
dikatakan kelas $\mathrm{C}$ jika kriteria pozzolan $\left(\mathrm{SiO}_{2}+\mathrm{Al}_{2} \mathrm{O}_{3}+\mathrm{Fe}_{2} \mathrm{O}_{3}\right)$ dengan data kandungan $\geq 50 \%, \mathrm{SO}_{3} \leq 5 \%$, $\mathrm{Na}_{2} \mathrm{O} \leq 1,5$, dan kuat tekan 75 Mpa.

Fly ash kelas $\mathrm{F}$ dan $\mathrm{C}$ masing-masing terdapat beberapa kriteria dan juga terdapat kandungan-kandungan yang mempengaruhi kualitas dari semen. Berikut merupakan data dari komposisi kimiawi bahan baku fly ash yang akan dilakukan penelitian:

Tabel 3. Komposisi Kimiawi Fly Ash

\begin{tabular}{|c|c|c|}
\hline \multirow[b]{2}{*}{ Komposisi } & \multicolumn{2}{|c|}{ Kelas } \\
\hline & $\mathrm{F}$ & $\mathrm{C}$ \\
\hline Pozzolan $\mathrm{SiO}_{2}+\mathrm{Al}_{2} \mathrm{O}_{3}+\mathrm{Fe}_{2} \mathrm{O}_{3}(\%)$ & 83,9553 & 74,0036 \\
\hline $\mathrm{SO}_{3}(\%)$ & 0,49324667 & 2,9785 \\
\hline $\mathrm{Na}_{2} \mathrm{O}(\%)$ & 2,21007333 & 2,202 \\
\hline $\begin{array}{l}\text { Kuat Tekan fly ash pada kapasitas campuran } \\
20 \%\end{array}$ & 95,53 Мра & 65,04 Mpa \\
\hline
\end{tabular}

Dari data yang diperoleh dapat diketahui kelas $\mathrm{F}$ memiliki kriteria kandungan Pozzolan 83,9553\%, $\mathrm{SO}_{3}$ 0,49324667\%, $\mathrm{Na}_{2} \mathrm{O} 2,21007333 \%$, dan kuat tekan 95,53 Mpa. Pada fly ash kelas C memiliki kriteria kandungan pozzolan 74,0036\%, $\mathrm{SO}_{3} 2,9785 \%, \mathrm{Na}_{2} \mathrm{O} 2,202 \%$, dan kuat tekan 65,04 Mpa.

\section{Pengolahan Data}

Pengolahan data dibagi menjadi dua tahap yaitu tahap fuzzy dan tahap TOPSIS. Tahap fuzzy terdiri dari pembentukan fungsi keanggotaan dan penentuan nilai keanggotaan. Pada tahap TOPSIS terdiri dari matriks elemen, normalisasi bobot matriks, solusi ideal positif, solusi ideal negatif, dan kedekatan relatif.

Tahap Fuzzy

Fungsi keanggotaan digunakan untuk menentukan bobot dari masing-masing nilai kriteria setiap alternatif.

\section{a. Bobot pozzolan pada alternatif $\mathbf{F}$}

Kriteria pozzolan pada alternatif $\mathrm{F}$ memiliki besar minimum $70 \%$

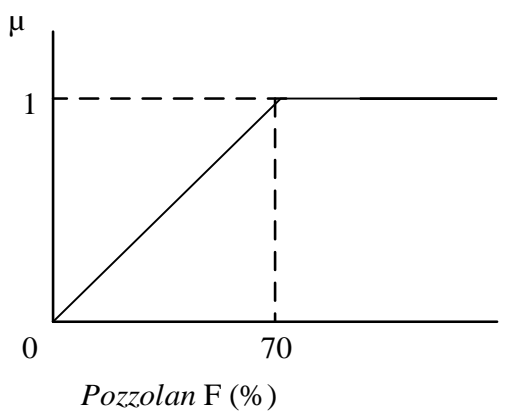

Gambar 3. Grafik Fungsi Keanggotaan Pozzolan F

$\mu K_{1} F=\left\{\begin{array}{cc}0 & ; x_{1} \leq 0 \\ \frac{x-70}{70} ; & 0 \leq x_{1} \leq 70 \\ 1 & ; x_{1} \geq 70\end{array}\right.$

Dimana $\mu K_{1} F$ adalah nilai keanggotaan dari pozzolan $\mathrm{K} 1$ pada alternatif fly ash kelas $\mathrm{F}$ dan $x_{1}$ adalah nilai pozzolan. Nilai pozzolan pada alternatif fly ash kelas $\mathrm{F}$ adalah $83,9553 \% \geq 70 \%$, jadi $\mu K_{1} F=1$.

b. Bobot pozzolan pada alternatif $\mathrm{C}$

Kriteria pozzolan pada alternatif C memiliki besar minimum $70 \%$ 


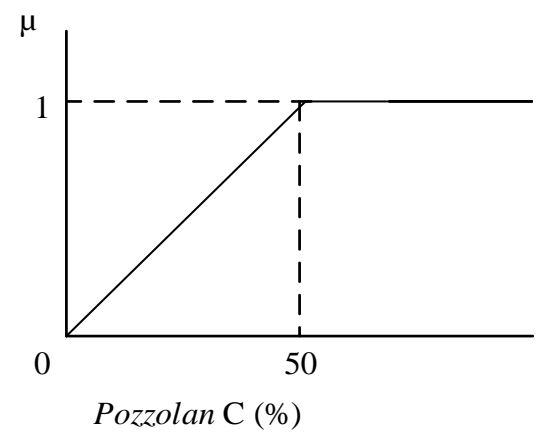

Gambar 4. Grafik Fungsi Keanggotaan Pozzolan C

$\mu K_{1} C=\left\{\begin{array}{cc}0 & ; x_{2} \leq 0 \\ \frac{x-50}{50} ; & 0 \leq x_{2} \leq 50 \\ 1 & ; x_{2} \geq 50\end{array}\right.$

Dimana $\mu K_{1} C$ adalah nilai keanggotaan dari pozzolan $\mathrm{K} 1$ pada alternatif fly ash kelas $\mathrm{C}$ dan $x_{2}$ adalah nilai pozzolan. Nilai pozzolan pada alternatif fly ash kelas $\mathrm{C}$ adalah $74,0036 \% \geq 50 \%$, jadi $\mu K_{1} C=1$.

\section{c. Bobot $\mathrm{SO}_{3}$ pada alternatif $\mathrm{F}$ dan $\mathrm{C}$}

Kriteria $\mathrm{SO}_{3}$ pada alternatif $\mathrm{F}$ dan $\mathrm{C}$ memiliki besar maksimum 5\%

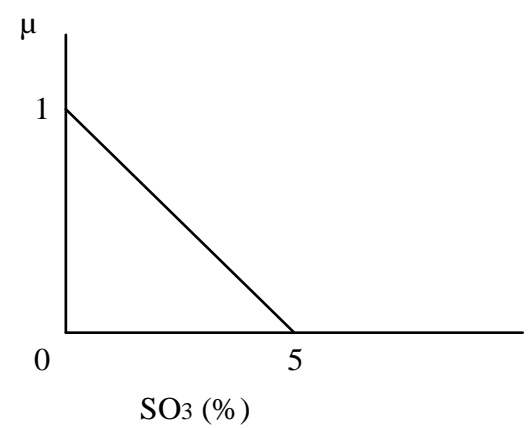

Gambar 5. Grafik Fungsi Keanggotaan $\mathrm{SO}_{3}$

$\mu K_{2} F=\left\{\begin{array}{cc}1 & ; x_{3} \leq 0 \\ \frac{5-x_{3}}{5} ; & 0 \leq x_{3} \leq 5 \\ 0 & ; x_{3} \geq 5\end{array}\right.$ an $\mu K_{2} C=\left\{\begin{array}{cc}1 & ; x_{4} \leq 0 \\ \frac{5-x_{4}}{5} ; 0 \leq x_{4} \leq 5 \\ 0 \quad ; x_{4} \geq 5\end{array}\right.$

Dimana $\mu K_{2} F$ dan $\mu K_{2} C$ adalah nilai keanggotaan dari $\mathrm{SO}_{3}$ (K2) pada alternatif fly ash kelas $\mathrm{F}$ dan $\mathrm{C}$, serta $x_{3}$ dan $x_{4}$ adalah nilai $\mathrm{SO}_{3}$. Nilai $\mathrm{SO}_{3}$ pada alternatif fly ash kelas F adalah $0,493 \% \geq 0$ dan $\leq 5$, jadi:

$\mu K_{2} F=\frac{5-x_{3}}{5}$

$\mu K_{2} F=\frac{5-0,493}{5}$

$\mu K_{2} F=0,902$

Nilai $\mathrm{SO}_{3}$ pada alternatif fly ash kelas $\mathrm{C}$ adalah $2,978 \% \geq 0$ dan $\leq 5 \%$, jadi

$\mu K_{2} C=\frac{5-x_{4}}{5}$

$\mu K_{2} C=\frac{5-2,978}{5}$

$\mu K_{2} C=0,404$

\section{d. Bobot $\mathrm{Na}_{2} \mathrm{O}$ pada alternatif $\mathrm{F}$ dan $\mathrm{C}$}

Kriteria $\mathrm{Na}_{2} \mathrm{O}$ pada alternatif $\mathrm{F}$ dan $\mathrm{C}$ memiliki besar maksimum 1,5\%. 


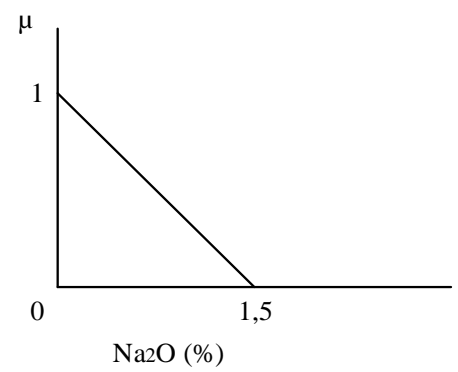

Gambar 6. Grafik Fungsi Keanggotaan $\mathrm{Na}_{2} \mathrm{O}$

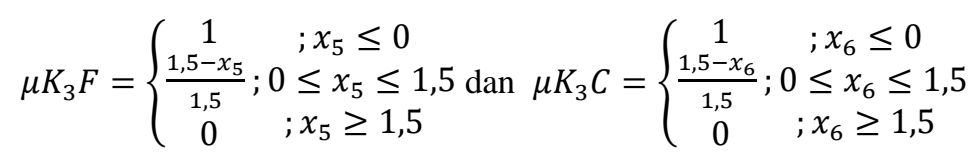

Dimana $\mu K_{3} \mathrm{~F}$ dan $\mu K_{3} \mathrm{C}$ adalah nilai keanggotaan dari $\mathrm{Na}_{2} \mathrm{O}$ (K2) pada alternatif fly ash kelas $\mathrm{F}$ dan $\mathrm{C}$, serta $x_{5}$ dan $x_{6}$ adalah nilai $\mathrm{Na}_{2} \mathrm{O}$. Nilai $\mathrm{Na}_{2} \mathrm{O}$ pada alternatif fly ash kelas $\mathrm{F}$ adalah $2,210 \% \geq 1,5$, jadi $\mu K_{3} F=0$. Nilai $\mathrm{Na}_{2} \mathrm{O}$ pada alternatif fly ash kelas $\mathrm{C}$ adalah $2,202 \% \geq 1,5$, jadi $\mu K_{3} \mathrm{C}=0$.

\section{e. Bobot kuat tekan pada alternatif $\mathbf{F}$ dan $\mathbf{C}$}

Kriteria kuat tekan pada alternatif $\mathrm{F}$ dan $\mathrm{C}$ memiliki besar minimum $75 \mathrm{Mpa}$.

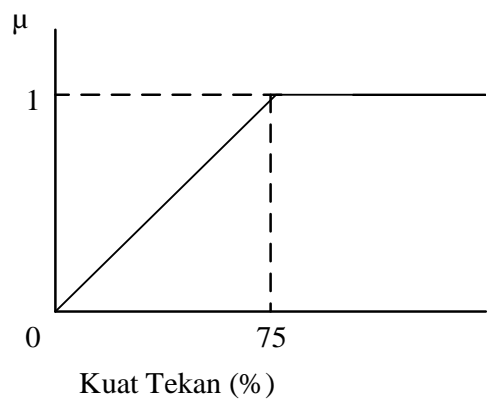

Gambar 7. Grafik Fungsi Keanggotaan Kuat Tekan

$\mu K_{4} F=\left\{\begin{array}{cc}0 & ; x_{7} \leq 0 \\ \frac{75-x_{7}}{75} ; 0 \leq x_{7} \leq 75 \\ 1, x_{7} \geq 75\end{array}\right.$ dan $\mu K_{4} C=\left\{\begin{array}{cc}0 & ; x_{8} \leq 0 \\ \frac{75-x_{8}}{75} ; 0 \leq x_{8} \leq 75 \\ 1 \quad ; x_{8} \geq 75\end{array}\right.$

Dimana $\mu K_{4} F$ dan $\mu K_{4} C$ adalah nilai keanggotaan dari kuat tekan (K4) pada alternatif fly ash kelas $\mathrm{F}$ dan $\mathrm{C}$, serta $x_{7}$ dan $x_{8}$ adalah nilai kuat tekan. Nilai kuat tekan pada alternatif fly ash kelas $\mathrm{F}$ adalah 95,53 Mpa $\geq 75$, jadi $\mu K_{4} F=1$. Nilai kuat tekan pada alternatif fly ash kelas $\mathrm{C}$ adalah $65,04 \mathrm{Mpa} \geq 0$ dan $\leq 75$, jadi:

$\mu K_{4} C=\frac{x_{4-75}}{75}$

$\mu K_{4} C=\frac{65,04-0}{75}$

$\mu K_{4} C=0,867$

Nilai keanggotaan $(\mu)$ menjadi bobot dari setiap nilai kriteria. Secara ringkas hasil pembobotan tertera pada tabel di bawah ini:

Tabel 4. Hasil Pembobotan Fuzzy

\begin{tabular}{ccccc}
\hline Alternatif & Pozzolan & $\mathrm{SO}_{3}$ & $\mathrm{Na}_{2} \mathrm{O}$ & Kuat Tekan \\
\hline $\mathrm{F}$ & 1 & 0,902 & 0 & 1 \\
$\mathrm{C}$ & 1 & 0,404 & 0 & 0,867 \\
\hline
\end{tabular}


Setelah memperoleh hasil pembobotan fuzzy kemudian dilakukan pengolahan data dengan menggunakan metode TOPSIS.

\section{Tahap TOPSIS}

a. Bobot Preferensi

Berikut merupakan tabel penilaian bobot nilai antar masing-masing kriteria:

Tabel 5. Bobot Nilai Antar Masing-masing Kriteria

\begin{tabular}{clc}
\hline No. & \multicolumn{1}{c}{ Keterangan } & Bobot \\
\hline 1. & Sangat Tidak Penting & 1 \\
2. & Tidak Penting & 2 \\
3. & Cukup & 3 \\
4. & Penting & 4 \\
5. & Sangat Penting & 5 \\
\hline
\end{tabular}

Pada tabel diatas menunjukkan bahwa apabila kriteria dengan bobot nilai 1 maka bisa dikatan sangat tidak penting, kriteria dengan bobot nilai 2 bisa dikatakan tidak penting, kriteria dengan bobot nilai 3 dikatakan cukup, kriteria dengan bobot nilai 4 dikatakan penting, dan apabila kriteria dengan bobot nilai 5 bisa dikatakan sangat penting.

Setelah dilakukan penilaian tingkat kepentingan antar masing-masing kriteria, maka akan dihasilkan bobot preferensi pada tabel di bawah ini:

\begin{tabular}{clc}
\multicolumn{3}{c}{ Tabel 6. Bobot Preferensi } \\
\hline No. & \multicolumn{1}{c}{ Kriteria } & Bobot Preferensi \\
\hline 1. & ${\text { Pozzolan } \mathrm{SiO}_{2}+\mathrm{Al}_{2} \mathrm{O}_{3}+\mathrm{Fe}_{2} \mathrm{O}_{3}(\min , \%)}_{2}$ & 5 \\
2. & $\mathrm{SO}_{3}(\max , \%)$ & 3 \\
3. & $\mathrm{Na}_{2} \mathrm{O}(\max , \%)$ & 4 \\
4. & Kuat Tekan & 5 \\
\hline
\end{tabular}

Dalam tabel bobot preferensi diketahui bahwa penilaian yang dilakukan berdasarkan pertimbangan tingkat kepentingan dari tabel 6.8. Masing-masing kriteria fly ash dapat diketahui bahwa pada kriteria pozzolan lebih penting dari $\mathrm{SO}_{3}$. Dikarenakan pozzolan mempunyai sifat reaktif seperti semen dibandingkan $\mathrm{SO}_{3}$ yang hanya memperbaiki sifat pengikatan dengan kurangnya kuat tekan yang dimiliki. Kriteria pozzolan sedikit lebih penting dari $\mathrm{Na}_{2} \mathrm{O}$. Dikarenakan pozzolan mempunyai sifat reaktif seperti semen dibandingkan $\mathrm{Na}_{2} \mathrm{O}$ yang hanya memperhatikan keretakannya. Kriteria pozzolan sama pentingnya dengan kuat tekan karena sifat reaktif pada pozzolan dan tingkat kekuatan pada kuat tekan sangat berpengaruh pada kualitas semen yang dihasilkan.

Tabel 7. Penempatan Bobot Preferensi

\begin{tabular}{ccccc}
\hline \multirow{2}{*}{ Alternatif } & Pozzolan & $\mathrm{SO}_{3}$ & $\mathrm{Na}_{2} \mathrm{O}$ & Kuat Tekan \\
& 5 & 3 & 4 & 5 \\
\hline $\mathrm{F}$ & 1 & 0,902 & 0 & 1 \\
$\mathrm{C}$ & 1 & 0,404 & 0 & 0,867 \\
\hline
\end{tabular}

\section{b. Normalisasi Matriks}

Bobot yang terbentuk dari tahap fuzzy kemudian dinormalisasikan. Berikut merupakan contoh perhitungan pada normalisasi pada bobot kriteria pozzolan $\mathrm{F}$.

$r_{11}=\frac{x_{11}}{\sqrt{\sum x_{i j}^{2}}}=\frac{1}{\sqrt{1^{2}+1^{2}}}=0,707107$

Dengan seluruh nilai dari $r_{i j}$ dapat dibentuk matriks $R$ dengan hasil sebagai berikut:

$R=\begin{array}{llll}0,707107 & 0,91264 & 0 & 0,755564\end{array}$

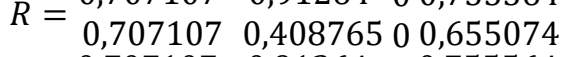

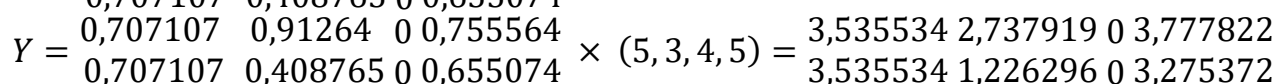

Hasil normalisasi bobot $(Y)$ diperoleh dari perkalian antara matriks $R$ dengan bobot preferensi. Setelah itu, dilakukan perhitungan nilai solusi ideal positif dan solusi ideal negatif.

Berikut merupakan perhitungan dari solusi ideal positif:

$a^{+}=\max \{3,535534 ; 3,535534\}=3,535534$ 
$a^{+}=\min \{2,737919 ; 1,226296\}=1,226296$

$a^{+}=\min \{0 ; 0\}=0$

$a^{+}=\max \{3,777822 ; 3,275372\}=3,777822$

$A^{+}=\{3,535534 ; 1,226296 ; 0 ; 3,777822\}$

Perhitungan nilai $A^{+}$yaitu dengan cara menentukan nilai terbaik dari hasil normalisasi pada masing-masing kriteria.

Berikut merupakan perhitungan dari solusi ideal negatif:

$a^{-}=\min \{3,535534 ; 3,535534\}=3,535534$

$a^{-}=\max \{2,737919 ; 1,226296\}=2,737919$

$a^{-}=\max \{0 ; 0\}=0$

$a^{-}=\min \{3,777822 ; 3,275372\}=3,275372$

$A^{-}=\{3,535534 ; 2,737919 ; 0 ; 3,275372\}$

Perhitungan nilai $A^{-}$yaitu dengan cara menentukan nilai terbaik dari hasil normalisasi pada masing-masing kriteria.

Setelah mendapatkan hasil perhitungan nilai terbaik $A^{+}$dan $A^{-}$dari hasil normalisasi pada masing-masing kriteria, maka dapat diketahui hasil solusi ideal positif dan solusi ideal negatif pada tabel di bawah ini:

Tabel 8. Nilai Terbaik $A^{+}$dan $A^{-}$

\begin{tabular}{ccccc}
\hline$A^{+}$ & 3,535534 & 1,226296 & 0 & 3,777822 \\
\hline$A^{-}$ & 3,535534 & 2,737919 & 0 & 3,275372 \\
\hline
\end{tabular}

Setelah diketahui hasil perhitungan nilai terbaik $A^{+}$dan $A^{-}$pada tabel di atas, maka akan dilakukan perhitungan separation measure positif dan separation measure negatif dengan perhitungan di bawah ini:

\section{c. Separation Measure (+)}

Untuk melakukan perhitungan Separation Measure dengan menggunakan persamaan 6.5 yaitu pada perhitungan di bawah ini:

$$
\begin{aligned}
& D 1^{+}=\sqrt{\frac{(3,535534-3,535534)^{2}+(1,226296-2,737919)^{2}+}{(0-0)^{2}+(3,275372-3,275372)^{2}}}=1,511622 \\
& D 2^{+}=\sqrt{\frac{(3,535534-3,535534)^{2}+(2,737919-2,737919)^{2}+}{(0-0)^{2}+(3,777822-3,275372)^{2}}}=0,50245
\end{aligned}
$$

Dari hasil perhitungan di atas diketahui bahwa hasil normalisasi baris pertama dikurangi dengan hasil dari $a^{+}$, sehingga dihasilkan $D 1^{+}=1,511622$. Pada $a^{-}$yaitu dilakukan perhitungan dari hasil normalisasi baris pertama dikurangi dengan hasil $a^{-}$sehingga $D 2^{+}$mendapatkan hasil 0,50245.

\section{d. Separation Measure (-)}

Untuk melakukan perhitungan solusi ideal negatif dengan menggunakan persamaan 6.6 yaitu pada perhitungan di bawah ini:

$$
D 1^{-}=\sqrt{\begin{array}{c}
(3,535534-3,535534)^{2}+(1,226296-1,226296)^{2}+ \\
(0-0)^{2}+(3,275372-3,777822)^{2}
\end{array}}=0,50245
$$

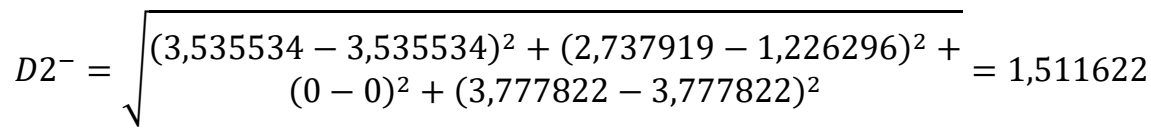

Dari hasil perhitungan di atas diketahui bahwa hasil normalisasi baris kedua dikurangi dengan hasil dari $a^{+}$, sehingga dihasilkan $D 1^{-}=0,50245$. Pada $a^{-}$yaitu dilakukan perhitungan dari hasil normalisasi baris pertama dikurangi dengan hasil $a^{-}$sehingga $D 2^{-}$mendapatkan hasil 1,511622. Setelah diketahui hasil perhitungan dari solusi ideal positif dan solusi ideal negatif maka akan dilanjutkan pada tahap kedekatan relatif.

\section{e. Kedekatan Relatif}


Kedekatan relatif merupakan tahap akhir untuk mengetahui hasil akhir dari perbandingan alternatif. Pada tahap ini yaitu perhitungan untuk menentukan hasil alternatif terbaik dengan jarak terpendek terhadap solusi ideal positif dan berjarak terjauh dengan solusi ideal negatif. Untuk menentukan kedekatan relatif dilakukan dengan menggunakan perhitungan di bawah ini:

$$
\begin{aligned}
& V 1=\frac{D 1^{-}}{D 1^{+}+D 1^{-}}=\frac{0,50245}{1,511622+0,50245}=0,24947 \\
& V 2=\frac{D 2^{-}}{D 2^{+}+D 2^{-}}=\frac{1,511622}{0,50245+1,511622}=0,75053
\end{aligned}
$$

Dari perhitungan kedekatan relatif diatas dapat diketahui hasil dari $V 1=0,24947$ dan $V 2=0,75053$, dimana $V 1$ merupakan fly ash kelas F dan V2 merupakan fly ash kelas C.

\section{f. Perangkingan Alternatif}

Pada tahap perangkingan maka dihasilkan alternatif terbaik dengan jarak terpendek terhadap solusi ideal positif dan berjarak terjauh dengan solusi ideal negatif. Hasil alternatif terbaik didapatkan dari hasil perhitungan dari kedekatan relatif yang diketahui bahwa $V 1=0,24947$ dan $V 2=0,75053$. Maka dari itu dari nilai $V$ yang merupakan jarak kedekatan setiap alternatif terhadap solusi ideal diperoleh nilai $V 2$ yang memiliki nilai terbesar.

\section{SIMPULAN}

Dalam menentukan pemilihan alternatif terbaik bahan baku fly ash kelas $\mathrm{F}$ dan $\mathrm{C}$ yaitu dengan menggunakan metode fuzzy-Topsis. Pada metode fuzzy-Topsis diperoleh hasil $V 1=0,24947$ dan $V 2=0,75053$. Dimana $V 1$ merupakan fly ash kelas F dan V2 merupakan fly ash kelas C. Dari hasil perhitungan menunjukkan $V 1<V 2$. Dari hasil pembahasan di atas dapat ditarik kesimpulan bahwa fly ash kelas $\mathrm{C}$ lebih baik digunakan sebagai bahan baku penunjang produksi semen dibandingkan dengan fly ash kelas F.

\section{DAFTAR PUSTAKA}

'Uyun, S., \& Riadi, I. (2011). A fuzzy Topsis multiple-attribute decision making for scholarship selection. Telkomnika, 9(1), 37-46. https://doi.org/10.12928/telkomnika.v9i1.643

Azizi, A., Aikhuele, D. O., \& Souleman, F. S. (2015). A Fuzzy TOPSIS Model to Rank Automotive Suppliers. Procedia Manufacturing, 2(December), 159-164. https://doi.org/10.1016/j.promfg.2015.07.028

Bahroini, A., Farmadi, A., \& Nugroho, R. A. (2016). Prediksi Permintaan Produk Mie Instan Dengan Metode Fuzzy Takagi-Sugeno. Klik - Kumpulan Jurnal Ilmu Komputer. https://doi.org/10.20527/klik.v3i2.62

Chu, T. C., \& Lin, Y. C. (2003). A fuzzy TOPSIS method for robot selection. International Journal of Advanced Manufacturing Technology, 21(4), 284-290. https://doi.org/10.1007/s001700300033

Kabir, G., \& Hasin, M. A. A. (2012). Comparative Analysis of Topsis and Fuzzy Topsis for the Evaluation of. International Journal of Quality Research, 6(3), 169-185.

Kusumadewi, S., \& Purnomo, H. (2010). Aplikasi Logika Fuzzy untuk Pendukung Keputusan (2nd ed.). Graha Ilmu.

Papilo, P., Djatna, T., Arkeman, Y., \& Marimin, M. (2018). Penerapan Fuzzy TOPSIS dalam Penentuan Lokasi Kawasan Pengembangan Rantai Pasok Bioenergi Kelapa Sawit. Agritech, 38(1), 79. https://doi.org/10.22146/agritech.12528

Sari, R. E. (2015). Pemilihan Alternatif Kualitas Kayu Terbaik Untuk Kerajinan Meubel Dengan Metode TOPSIS. Seminar Nasional Informatika 2015, 211-216. http://e-journal.potensi utama.ac.id/ojs/index.php/SNIf/article/view/268

Sutter, L., Hooton, R. D., \& Schlorholtz, S. (2013). Methods for Evaluating Fly Ash for Use in Highway Concrete. In Methods for Evaluating Fly Ash for Use in Highway Concrete. https://doi.org/10.17226/22483

Syahputra, M. R. (2014). Aplikasi Fuzzy-TOPSIS Dalam Melakukan Seleksi Pemilihan Perumahan. Jurnal Mantik Penusa, 15(Fakultas Manajemen dan Informatika Pelita Nusantara), 123-128. file:///e:/Users/S u s e n o/Downloads/245-Article Text-584-1-10-20171028.pdf 